\title{
THE ANALYSIS OF THE U.S. EXTERNAL DEBT IN TERMS OF FACING THE CHALLENGES OF THE WORLD ECONOMIC DEVELOPMENT
}

\author{
Andrii Pin \\ Department of International Economics \\ Ternopil National Economic University \\ 11 Lvivska str., Ternopil, Ukraine, 46000 \\ Rockgorn@gmail.com
}

\begin{abstract}
The up-to-date approaches to external debt and its effects on economic processes entrench the standpoint of debt financing being the distinctive feature of the modern inclined-to-liberalization world. Subsequently, unhampered capital flow between economies is the offspring of macroeconomic equilibrium, since the allocation of capital based on barrier-free movement pays the way for factor prices levelling. Given these points, commodity prices develop a propensity for adjustment, financial system acquires sustainability and reliability. This research builds on existing knowledge in the domain of debt and is conducted in pursue of analyzing the U.S. external debt and effects it has on both the U.S. Economy and the global economy. Prior to looking into the external debt itself, the research study reveals the latest world financial and economic tendencies, the distinguishing features of which are low interest rates and smoldering economic growth. The IMF dubbed this economic agenda as ".... low growth, low-rate area” [1]. Along similar lines, the results of the research lend firm support to the view that the U.S. external debt poses little threat to the world economy in the short-run, since the U.S. economic growth outpaces debt servicing costs build-up. However, in case of the emergence of an economic decline, the United States may face challenges of debt servicing in the long-run perspective, hence fail to comply with the sacred principles of debt relationship such as timeliness and solvency.
\end{abstract}

Keywords: the U.S. external debt, the U.S. national debt, debt financing, debt effects, solvency and liquidity.

DOI: 10.21303/2504-5571.2017.00250

(C) Andrii Pin

\section{Introduction}

Should an economic agent run into a situation of total spending outrunning total income, it is mandatory to look for the financial sources in order to raise the extra funds [2]. Admittedly, there are roughly two options such as borrowing from either banks or capital market and assets selling a market participant can choose in order to finance troubling budget items. Doubtlessly, by going to borrow on a regular basis in the long term, an economic agent will inevitably run up against a mountain of debt, which is highly likely to turn into an onerous financial burden.

While viewing debt from the macrolevel perspective, it is necessary to emphasize the importance of carrying out a reasonable debt management policy as the inherent component of sustainable development and national security. It is a well-established fact that both advanced and developing economies worldwide intensively engage debt financing for various purposes, most of which concern dealing with budget deficit and covering programs falling into social domain. Meanwhile the asset selling option is at great demand in the nongovernmental sector, the fraction of funds a government is used to accumulating by selling assets is infinitesimally close to zero. On this logic, there is only one option left for a government to draw on in order to catch up with spending such as borrowing the extra funds. In case of subjecting to chronic budget deficits a government suffers threatening debt the burden of which is in all likelihood to put pressure on a country in the long-run.

By conjuring up a hypothetic situation under the conditions of which a government has already built up the substantial amount of debt, it is mandatory to consider two financial spillovers and their effects on an economy. Firstly, being both at the state of full employment and in need of receiving a loan, a government wedges between private sector's demand for the external financial resources for investment spending and financial markets supply of thereby. Literally, a government affects the equilibrium of a capital market, inducing increase in interest rates and hampering economic growth in the long-term. Secondly, a current budget deficit covered by a debt financing is likely to undermine programmes counted in the items of future budgets. Besides debt financing, raising tax and cutting off government spending are another options to cover the gap, but doing 
so in times of impending debt burden may cause both more pressure on tax payers and the socially impaired. As a consequence, intensified taxation will cause investors' sentiment to come out, hence leading to capital outflows and growing reluctance to grant holiday on interest and capital repayments, debt prolongation or extra loans. Importantly, should a government affirms the need for more borrowings, it will undoubtedly fetch up in debtor's prison.

Of particular importance to research on debt matter is external debt and its effects on economy. Being a structural element of a country's national debt, an external debt bears more menace to financial and economic stability than the liabilities of government to its residents. The very definition of an external debt refers to financial debt or obligation a resident owes a nonresident usually as a result of certain business operations [3]. At this point, the most important aspect of an external debt is that in case of insolvency capital movement adopts a procyclical feature, hence value leaves an economy in the time the latter requires it at most. Taking into account the fact that advanced economies have developed substantial amounts of national debt, the noticeable fraction of which accounts for liabilities to nonresidents, it is of indisputable importance to give an account of the nature of national debt, putting a special emphasis on the external constituent. Of particular importance is the analysis of the U.S. national and external debt, since the stability of the undisputed world economic leader, the national currency of which is international money and accounts for the substantial fraction of international reserves of countries across the world, is of the highest priority as to ensuring world sustainable economic growth and financial stability.

\section{Literature review}

There is no denying that a number of economists have dedicated their research studies to the investigation of the matter of debt and indebtedness. Given this orientation, it is well worth indicating the fact that there are chiefly two contradicting perspectives from which the matter of national and external debt is viewed.

Firstly, national debt is approached from a burden-free standpoint. With this in mind, national debt is regarded as the redistribution of income between the owners of debt securities at a certain point in future. Hume, Smith and Ricardo, the adherents of the English Political Economy, set up the economic category of "healthy finance", putting forward an argument that debt financing is at odds with financial stability, which amounted to deficit-free budgeting [4].

A conflicting viewpoint is supported by Lerner, Keynes and Krugman, who strenuously defend the essentiality of debt financing in an economy's strategic development [5-9]. Peculiarly, Lerner devised the concept of functional finance, suggesting that national debt can be effortlessly accumulated and will not draw an economy in excessive unbearable expenditures or losses [8,9]. Keynes adopts the position that debt financing should be directed at real sector qualitative and quantitative extension [6]. This means sustainable economic growth, which creates favorable conditions owing to the multiplication effect of involved loans. Thus, economic growth guarantees timely and complete debt servicing and minimizes risks and harmful effects national debt may have on an economy. Of particular importance to this research is the view of contemporary American economist Paul Krugman [2]. The scientist draws attention to opportunity-oriented nature of debt [7]. That is to say, by achieving and sustaining the pace of economic growth more intense than the accrual of debt, strategic economic planning may overlook permanent accumulation and build-up of debts [2].

\section{Purpose and goals}

The purpose the current research seeks to achieve is to provide a better understanding of the nature and effects of the U.S. external debt and dissect whether the current value of the U.S. external debt poses a threat to both the U.S. economy the world economy; outline core theoretical and fundamental essentials of both national and external debt.

In pursuit of fulfilling the purpose of this research paper, several goals have been set and can be defined as follows: 
1. To give an account of the current and historical economic and financial trends and tendencies. With the context of this goal, it is necessary to highlight the de facto effects the recent economic events have had on the world economic agenda.

2. It is of vital importance to find out the place of external debt in the domain of national debt and gross external debt.

3. Carry out the analysis of the U.S. external debt by calculating the major indicators. Of particular importance in terms of this goal is to demonstrate the extent to which the U.S. economy is subjected to debt burden. Particularly, indicators are to be used to define vulnerability, solvency, repayment capacity, liquidity, reliance on short-term financing and repayment risks.

\section{Methodology}

The theoretical pillar of the current research paper consists in the views of prominent economists investigating the matter of debt and related issues. The statistical data for analysis derives from the data repositories of official institutions. The methodological approaches applied in the research paper for attaining the purpose and achieving accompanying goals include customary methods of obtaining knowledge such as observation, analysis, synthesis, comparison, deduction and induction.

\section{Results}

Prior to investigating the matter of national debt, it is well worth outlining the current trends of the global financial environment and the world economy. The agenda of the global financial system has prominent features such as low interest rates, weak growth and uncertainty about vectors of political development and structural drawbacks for banks [1]. Financial risks have been invigorated since the beginning of the second quarter of 2016, namely United Kingdom's exit from the EU and high unpredictability with respect to political events in Europe. Far-reaching repercussions for financial stability and economic growth are also intensively fueled by legacy burden, wealth inequality, the profitability shrinkage of advanced economy banks, sensitive shortage of bond yields, impacted lending conditions, etc [5]. According to the analytical data contained in the IMF 2016 Global Economic Report, the global growth rate in the first half-year of 2016 dwelled on 2.9 percent, which has turned out to be somewhat lower than in the previous year [5]. Such a protracted slowdown, combined with low inflation levels and cheap-money monetary policy, has created adverse and difficult circumstances for bonds with medium-term and long-term maturity to provide their owners with increasing yields. Inversely, the bond yields have been keeping to edge lower, just as global real long-term interest rates did throughout the first six months of 2016 [1].

Political collisions between Russia and the Western World also contributed to a visible decrease in crude oil prices at the end of the first half-year of 2014, which in turns paid the way for commodity prices to slide down. However, as chronic political rivalry stepped into the phase of remission, crude oil prices began to recover in the second half-year of 2016. Although the January of 2016 has broken a record by becoming the month of the lowest crude oil prices in a 10-year period, the oil prices rallied up by 50 percent up to $\$ 45$ at the end of the summer of 2016 [5]. The economic trend of partial recovery in commodity prices is also applicable to for coal prices, which have gone 32 percent up since the February of 2016. However, the prices of natural gas have still been rolling down due to weakening demand in Asia and oil overproduction in Russia, having reached 6-percent decrease since the February of 2016. Apart from energy supply, nonfuel commodities such as agricultural and metals have gained some value by 9 percent and 12 percent respectfully. Thus, partial recovery in commodity prices indicates the existence of a recovery stage, which can be regarded as somewhat steadfast, though crawling and liable to recession. The modest recovery in commodity prices has gone along with the stabilization of exchange rates. The major exporters of commodities (Russia, Brasilia, South Africa, etc.) have watched their national currencies appreciate in relation to the reserve currencies. The appreciation of these currencies has contributed to the strengthening of investors' sentiment, which was related to the expectations of low interest rates in advanced economies [5]. Of equal importance in terms of this research is the economic agenda of the United States of America. There is no point in doubting the fact that the United 
States plays the crucial role in the world economy, since the country's currency fulfills the function of world money and literally every country holds a great deal of its international reserves in the U.S. dollar. Ranking above others, it is worth mentioning that the U.S. demand for commodities accounts for a mountain of supply generated by newly industrialized countries, especially China, India and some of East-Asian countries. Being responsible for the creation of a slew of added value, the U.S. companies make direct investments in those countries, fueling their economies with opportunities for a robust national income, employment and overall well-being. For instance, the U.S.-China economic relations distinctly demonstrate the interdependence between the advanced and newly industrialized economies. The United States runs chronic trade deficits with China and the figure ran into \$365.7 billion in 2015 [10]. Not surprisingly, the U.S.-China trade deficit of 2015 established a world record as the largest trade deficit amount. This amount is highly likely to keep climbing up, for the U.S.-based business entities allocate their production facilities in China in order to benefit from lower wages Chinese labor market offers, hence reducing cost of production. On these grounds, the majority of the U.S. imports is attributable to those U.S.-based companies, which in turn require the low interest rate environment in order to keep operating on the market. To sustain the U.S. interest rates low and keep Yuan relatively low to the U.S. dollar, China purchases the U.S. Treasuries and thus invigorates the U.S. economy with highly liquid capital. Should unfavorable circumstances occur and demand for the U.S. debt securities start to diminish, the U.S. interest rates will edge higher, foreign investments flow will weaken, USD will depreciate and then press down bond yields and thus demand will further decrease. Taking into account the role of both the U.S. dollar and China commodity volume in the world economy, the China-USA economic relations are the pillar of the world economic stability and sustainable development. Thus, the U.S. sustainable economic development and growth is a must have of the world economy to remain healthy and lasting in the long-run.

First and foremost, as have been noted the United States is currently the world economic locomotive. However, over the last few decades the U.S. contribution to the world economic growth has noticeably shrunk [11]. While excluding a few remarkable moments of intensification in that period, the United States appears to have been losing momentum for the last half of century [5]. There is compelling evidence in support of the claim that although consumption growth underpinned by expanding payrolls and strong labor market has still been and is expected to remain sturdy and lasting, the United States is highly likely to run up against slow-down problem, for 1.1-percent economic growth is the best perspective economic and financial analytics give [5]. Among factors exerting pernicious influence on the U.S. economic vector of development, the most threatening ones are a considerable drawdown of inventories, tottering business fixed investment, capital spending shrinkage, affected by appreciating dollar export-oriented industries and decline in nonresidential investment [5].

To give a clear illustration of the U.S. economic current agenda and perspectives, some attention should be devoted to the economic dynamics in historical view. On the basis of the evidence currently available, the U.S. economic contribution to the world economy has shrunk by half since 1960 (to the date, it amounts to 22 percent of the global GDP), when the GDP equaled 40 percent of the world GDP (Patton, 2016). While the pace of economic growth measured in the U.S. GDPto-the World GDP ratio remained stable in the 1960s and up to the beginning of 1970s, the period from 1968 to 1980 featured gasoline shortage, immoderate inflationary pumping, oil embargo, expediting corporate innovative activity with relative effects on production facilities (automatization) and other economic and social trends, including social disturbances such as, for example, racial collisions [11]. On the other hand, the amount of the U.S. national debt (this definition encompasses public debt, government debt, sovereign debt and foreign debt) has been accumulating since the American Revolutionary War (1775-1783), particularly since the time when the federal government was coerced into adding balance sheet items standing for financial liabilities related with debt formation. At the moment, the U.S. national debt clock strikes almost \$20 trillion, revealing the fact that the USA is by far the largest debtor in the world [12].

Of peculiar importance to the current research is the U.S. external debt, or foreign holdings of the U.S. securities. A special emphasis should be placed on the U.S. debt securities such as the 
U.S. Treasuries. The U.S. external debt includes both the fraction of national debt accountable for the liabilities of a central government, government agencies and public corporations controlled by a government to foreign economic agents plus debt owed by the U.S. private sector to foreign economic entities. For a deeper understanding of the U.S economic agenda and historical trends, the dynamics of the U.S. economic growth and debt accumulation is provided in the accompanying figure (Fig. 1).

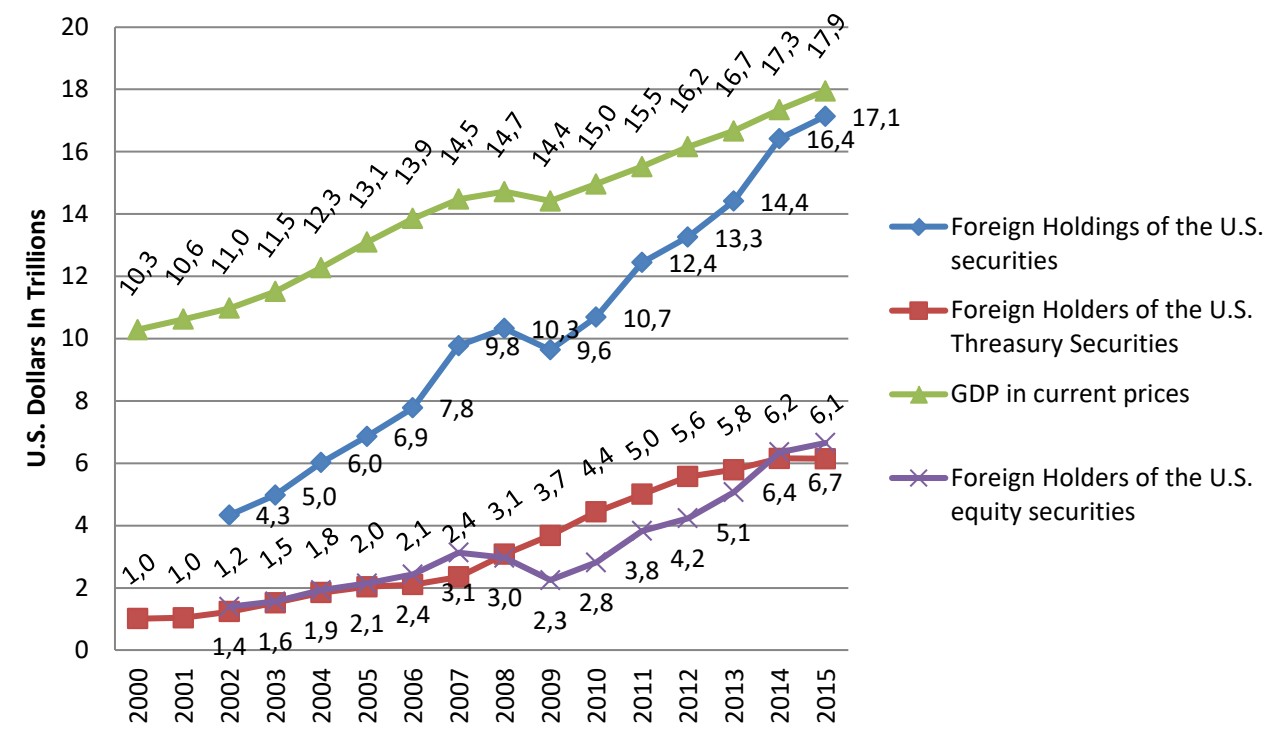

Fig. 1. The dynamics of the U.S. economic growth and external debt accumulation Source: calculated by the author on the basis of the data derived from the U.S. Department of Treasury [13-16]

In terms of the U.S. external debt, it is necessary to bear in mind the fact that it is constituted of both debt and equity securities. In turn, debt securities encompass the liabilities of the U.S. Treasury, U.S. Agency and Corporate (non-Treasury and non-security debt). The available evidence on the fig. 1 seems to suggest that the growth of the U.S. external debt outruns the pace of the U.S. economic growth. Besides, the amount of liabilities to the foreign holders of the U.S. Treasury Securities increases at the same pace as the U.S. GDP does, which indicates the strong long-term economic relations between the United States and its partners, particularly those foreign holders of the U.S. Securities. Furthermore, the amounts of both debt and equity securities hold by foreign economic agents generally draw abreast, indicating similar demand for the U.S. debt and equity securities on the world capital market. At this point, the financial credibility of the U.S. Treasuries regarded by far as the most stable securities equals to that of equities. Taking into account the fact of the U.S. external debt is building up more invigoratively than the pace of economic growth, it is of indisputable importance to carry out in-depth research into the area of the U.S. debt.

Prior to moving from the shallow outline of the U.S. debt issues lied out above to the thorough analysis, it is well worth clarifying the nature of and difference between national debt and external debt by providing consecutive breakdown of the given definitions. In this context, of particular importance to the current research are the dimensions and frameworks of external debt.

National debt defines liabilities a specific country represented by a government owes its creditors. To be attributed to national debt, a liability must be outstanding and exist in time and space. The formation of a debt liability is the economic action where a creditor provides certain amount of economic value in the form of financial and nonfinancial assets to a debtor under contractual agreement [3]. The definition of the national debt is used interchangeably with government debt, sovereign debt and country debt. Particularly, in the United States national debt breaks down into public debt and intergovernmental debt. Out of \$20 trillion of the U.S. national debt, public debt accounts for the two-thirds and is owed by the U.S. government to both residents and nonres- 
idents of various economic sectors (banks, households, nonfinancial corporations, governments), which holds official certificates promising to repay borrowed money at a certain rate, often fixed, of interest at a specified time and denominated in Treasury bills, bonds and notes [17]. The rest fraction of the U.S. national debt is the government debt owed by the government to itself and denominated in Government Account securities. The major holders of those securities are trust funds and Social Security Fund. Within the context of public debt, it is necessary to distinguish the fraction of debt a government owes to its foreign creditors.

According to the Guide for Compliers and Users elaborated by the International Monetary Fund (IMF), the definition of gross external debt encompasses the outstanding amount of current liabilities consisted of principal and interest and owed by residents to nonresidents of an economy [3]. However, the external debt should be approached not only as the element of national debt, but as an independent economic category. From the perspective of national debt, hence government view, external debt is a fraction of a country's national debt borrowed by the central government from foreign economic agents such as banks, nonfinancial corporations, international financial institutions, governments and government agencies. As an independent economic category, external debt represents all financial liabilities the residents of both different types of ownership and various economic sectors owe to the corresponding nonresidents. In a nutshell, as the component of national debt, external debt represents the liabilities of government and related organizations to foreign economic agents, meanwhile as an independent category it represents the liabilities of all economic agents of a specific country to the economic agents of a foreign country.

Additionally, it is reasonable to give a window into publicly guaranteed private sector external debt represented by debt securities emitted by private sector, but contractually guaranteed by a public sector, which embraces monetary authorities, general government and public financial and nonfinancial corporations (entities the half of voting power of which owned by a government). Although such debt is incurred by private sector, in case of poor solvency or total insolvency a government is obligated to shoulder a debt burden.

The most important aspect of the phenomenon of external debt is that by discharging liability a debtor incurs outflow of economic value from their economy. Meanwhile the fraction of national debt, which excludes liabilities to foreign economic agents, does not entail outflow of capital in the form of debt payments but redistribution of economic value between debt securities holders and their corresponding debtors, external debt inherently begets capital outflow, hence has unfavorable effects on the balance of payments, national currency and overall financial sustainability of a debtor-country.

Make no mistake, external debt can be described in secular language as a time bomb, for slowdown in economic growth incurs investors' sentiment and thus the holders of debt securities claim debt repayments from borrowers on short notice. Such panic-stricken stampede on the debt securities market drives market prices far below the nominal prices of securities and launches the process of market bubble formation and expansion. The rapid contraction of the market prices of debt securities is the final stage of the economic cycle dubbed as a bubble. Effervescent market behavior leads up to erratic selloff of debt securities at miserable prices, ending up at tremendous losses, which investors/creditors inevitably suffer. It all boils down to the fact that external debt trends and tendencies a country features are the starting point of economic analysis in the context of research on the matter of the U.S. debt. To pour lucidity on the matter of the U.S. external debt, it is worth taking into account the notion of the American economist Douglas Holtz-Eakin, who put forward an argument that the U.S. Treasury is highly viable security and the emergence of any shortcomings or "cracks" in that system would undermine the global financial system and is likely to engender a global economic recession [17].

The Fig. 2 elicits the fact of constantly increasing external debt-to-GDP ratio, indicating the likelihood of an apparent increase in debt crisis threat under adverse economic circumstance. However, the accretion of the U.S. export has been significantly outrunning external debt service costs for over the last decade and the friction of short-term debt in the total external debt tends to slide painstakingly during the last five years. Associated with the arguments aforementioned is a claim that although the accumulation of debt outpaces the build-up of the GDP, the United States demonstrates robust repayment capacity and tapering-off reliance on short-term financing. Despite 
of the U.S. international reserves shrinking in relation to short-term external debt accumulation, the country shows high level of liquidity and solvency.

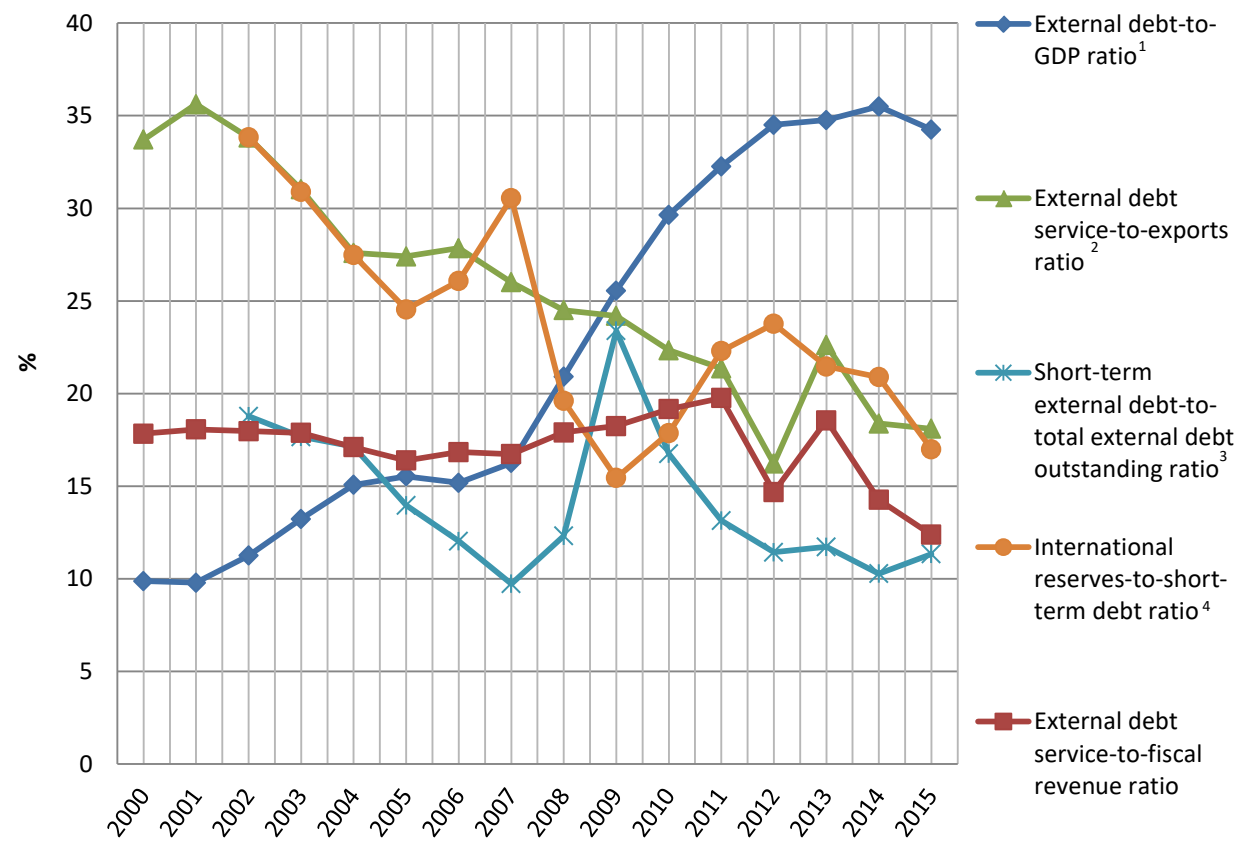

Fig. 2. The dynamics of the selected external debt indicators

1. The external debt equals to the foreign holders of the U.S. Treasury Securities

2. The short-term external debt is the foreign holders of the short-term U.S. Treasury Securities; the total external debt outstanding is the foreign holders of the U.S. Treasury Securities.

3. The short-term debt is the holders of the short-term U.S. Treasury Securities

Source: calculated by the author on the basis of the data derived from The Statista Portal, 2016;

The U.S. Department of Commerce, 2016; Treasury Direct, [3, 10, 13, 14, 17-20]

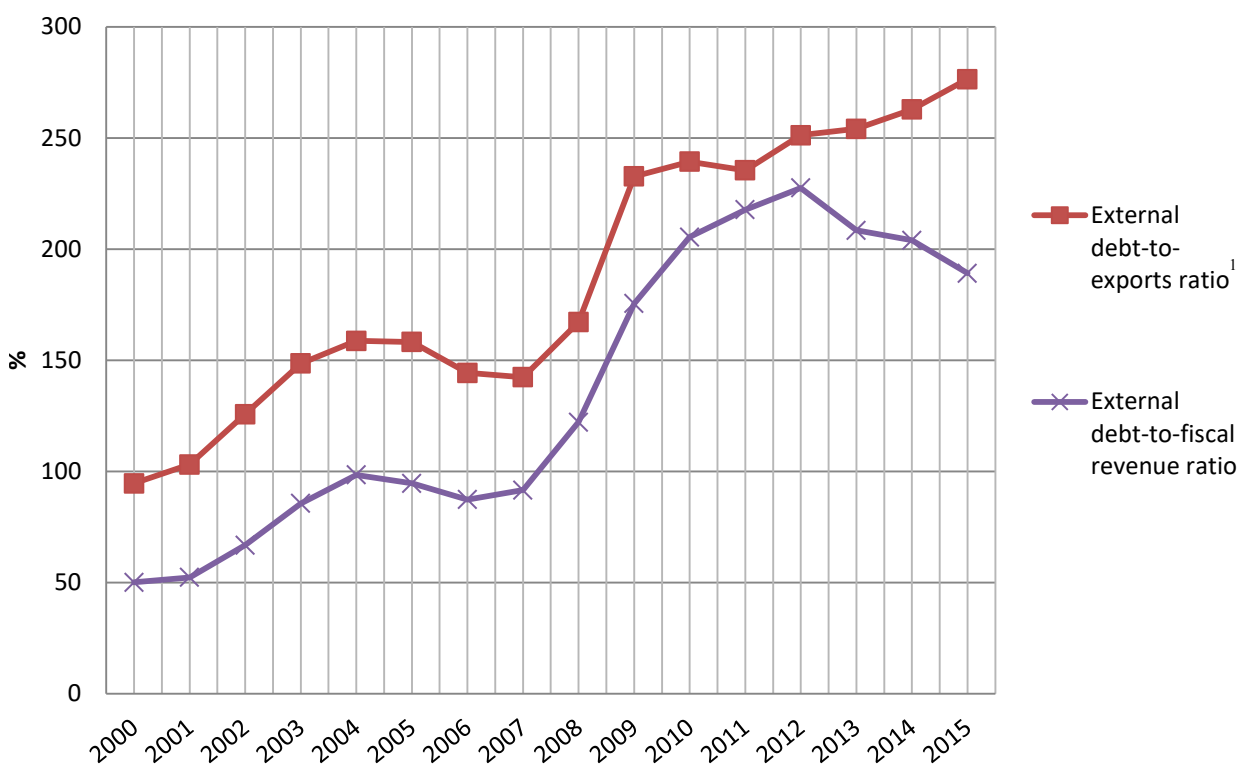

Fig. 3. The dynamics of the selected external debt indicators

1. The external debt equals to the foreign holders of the U.S. Treasury Securities

Source: calculated by the author on the basis of the data derived from The Statista Portal, 2016;

The U.S. Department of Commerce, 2016; Treasury Direct, [3, 10, 13-15, 18-20] 
Pursuant to the Fig. 3, the United States seems to have run up against nagging debt burden, which cannot be covered up by export revenues and public resources for payment. However, the American economist P. Krugman (2013) puts forward an argument that the absolute value of debt is poorly informative for conducting the accurate analysis of a country's debt issues [2]. The economist strenuously argues that the debt-to-GDP ratio should be given priority while carrying out analysis. On these grounds, as shown in the Fig. 2 the external debt-to-GDP ratio has been less than $35 \%$ over the last half of decade, eliciting the fact that United States bears relatively little debt burden against the country's foreign partners. Moreover, the external debt-to-GDP ratio has been displaying the uneventful and stable tendency to near-35-percent development since 2011 with an apparent shift to decrease in 2015 (Fig. 2). Moreover, the Fig. 2 also demonstrates the solid trend of the external debt-to-fiscal revenue ratio having been sliding down since 2013. On this logic, by sustaining economic growth at a pace more intense than that of the build-up of external debt service costs, the United States will effortlessly cope with external debt payments in terms of timeliness and completeness. However, in case of economic slow-down, the world economic leader may run into difficulty in debt servicing and repayment.

\section{Discussion}

On the basis of the analysis introduced above, it is worthwhile considering the importance of external debt while conducting voluminous analysis of a county's national debt. The results of the current research give a window into contingent threats and opportunities that external financing based on the principles of serviceability, timeliness and obligation may bring along. As have been noted in the results paragraph of the research, the U.S. external debt represents little threat, since the country sustains high level of credibility and constantly proves its solvency and financial stability.

The results are relevant for being applied to the analysis of world financial stability at large and the health and robustness of the U.S. economy and financial system in particular. The fact of the U.S. economic growth, being at a pace more intense than the accrual of external debt service costs indicates financial stability and sustainability in the short-run perspective. However, from the standpoint of the long-run effect, the U.S. external debt may convert into a morbid economic formation, which will pose a danger to the entire global economy.

This research paves the way for further analysis of the nature of the U.S. external debt. Particularly, it is of paramount importance to carry out the long-run analysis of the effects of the U.S. external debt and indebtedness on the U.S. economy in particular and the world economy in general.

\section{Conclusions}

On the basis of the research study conducted, it is plausible to draw the following conclusions.

Firstly, the current tendencies of global financial system and world economy display tapering-off growth and low-interest vector of development. In-house disturbances in the EU related to United Kingdom's abandonment, rigorously fluctuating oil prices and widely-extended "cheap money" monetary policy predetermine unfavorable expectations for long-term and medium-term securities, on which their owners count in anticipation of robust yields. In light of all this, the dwindling profitability of securities is highly likely to pose a danger to countries with substantial amount of national debt, but especially those with noticeable external debt.

Secondly, external debt should be viewed both as the component of national debt and as an independent category. As the component of national debt, external debt represents the liabilities of government and related organizations to foreign economic agents, meanwhile as an independent category it represents the liabilities of all economic agents of a specific country to the economic agents of a foreign country.

Thirdly, the analysis of the debt-related ratios has showed that the current U.S. economic growth outpaces the build-up of the external debt servicing costs. It all boils down to the fact the U.S. economy is not under the immediate threat of the emergence of a debt crisis. However, in the long-run perspective, the United States may face formidable challenges as to solvency and liquidity in case of an economic decline. 


\section{References}

[1] Chapter 1. Financial Stability Challenges in Low-Growth, Low-Rate Area (2016). Global Financial Stability Report (GFSR). International Monetary Fund, 1-48. Available at: http://www.imf.org/external/ pubs/ft/gfsr/2016/02/pdf/c1.pdf

[2] Krugman, P., Wells, R. (2012). Economics. New York: Worth Publishing Ltd., 1157.

[3] External Debt Statistics: Guide for Compilers and Users (2003). International Monetary Fund. Available at: https://www.imf.org/external/pubs/ft/eds/Eng/Guide/

[4] Holtfrerich, C., Ludwig, C. (2013). Government Debt in Economic Thought of the Long 19th Century. School of Business \& Economics, 4, 32.

[5] Chapter 1. Global Prospects and Policies (2016). Subdued Demand: Symptoms and Remedies. International Monetary Fund, 1-62. Available at: https://www.imf.org/external/pubs/ft/weo/2016/02/pdf/cl.pdf

[6] Keynes, J. M. (1971). The Economic Consequences of the Peace. doi: 10.1007/978-1-349-00864-3

[7] Krugman, P. (2015). Nobody Understands Debt. New York Times. Available at: http://www. nytimes.com/2015/02/09/opinion/paul-krugman-nobody-understands-debt.html?_r=0

[8] Lerner, A. (1948). Income, employment and public policy; essays in honor of Alvin H. Hansen. New York: Norton, 141.

[9] Lerner, A. (1955). Chapter 30. Functional Finance and Federal Dept. Readings in fiscal policy. Homewood: Richard D. Irwin, Inc., 468-478. Available at: http://public.econ.duke.edu/ kdh9/Courses/Graduate\%20Macro\%20History/Readings-1/Lerner\%20Functional\%20Finance.pdf

[10] International Economic Accounts (2016). Bureau of Economic Analysis. U. S. Department of Commerce. Available at: http://www.bea.gov/international/

[11] Patton, M. (2016). U.S. Role In Global Economy Declines Nearly 50 \%. Forbs. Available at: http:// www.forbes.com/sites/mikepatton/2016/02/29/u-s-role-in-global-economy-declines-nearly-50/\#20a2a70e59c1

[12] U.S. Debt Clock. (2016). Available at: http://www.usdebtclock.org

[13] Interest Expense on the Debt Outstanding (2016). Treasury direct. Available at: https://www. treasurydirect.gov/govt/reports/ir/ir_expense.htm

[14] Major Foreign Holders of Treasury Securities. (16.11.2016). Available at: http://ticdata.treasury. gov/Publish/mfhhis01.txt

[15] Foreign Portfolio Holdings of U.S. Securities as of June 30, 2015 (2016). Department of the Treasury, Federal Reserve Bank of New York, Board of Governors of the Federal Reserve System. Available at: http://ticdata.treasury.gov/Publish/shl2015r.pdf

[16] Report on Foreign Portfolio Holdings of U. S. Securities as of June 30, 2007 (2008). Department of the Treasury, Federal Reserve Bank of New York, Board of Governors of the Federal Reserve System. Available at: http://ticdata.treasury.gov/Publish/shl2007r.pdf

[17] Long, H. (2016). Who owns America's debt? Available at: http://money.cnn.com/2016/05/10/ news/economy/us-debt-ownership/

[18] United States: National debt from 2010 to 2020 (in billion US dollars) (2016). The Statistics Portal. Available at: https:/www.statista.com/statistics/262893/national-debt-in-the-united-states/

[19] International Trade in Goods and Services (2016). UNCTAD. Available at: http://unctadstat. unctad.org/wds/ReportFolders/reportFolders.aspx

[20] U.S. International Reserve Position (2016). U.S. Department of the Treasury. Available at: https://www.treasury.gov/resource-center/data-chart-center/IR-Position/Pages/default.aspx 